\title{
Independent Evaluation Policy for Admission of New Students Examination Outcome Phase
}

\author{
Suandi Silalahi, Sugiarto, Nurhattati, Suryadi, Eliana Sari
} Abstract: This study was conducted to obtain valid information
and can be trusted on the initial conditions (antecedents), policy
implementation, and variations in the results (outcomes) Exam
Independently implementation at the University of North
Sumatra. In evaluating the aspects of the Exam independently
by USU, it is carried out through a formal evaluation approach.
Formal evaluation uses laws, program / policy documents,
interviews with office holders in this case as policy
implementers by identifying, defining, and specifying policy
objectives and targets. (Luankali, 2007). In formal evaluation the type of evaluative criteria that is most often used is effectiveness. Evaluating the implementation of the Examination Policy independently at the University of North Sumatra as an object of research to: (1) assess how much a policy can achieve its objectives; (2) provide guidance to policy implementers regarding how smoothly the trip or the policy process is implemented; and (3) providing important indicators for policy makers in the future; and furthermore, (4) evaluating the outcome (outcome) of the policy is aimed at seeing the extent to which the results of the policy implementation result. In this evaluation, measures and interpretations of the success of the policies are carried out which include: evaluation; implementation of new student admission policies through the Independent Examination at USU. This research is a type of evaluation research, policy / program implementation in the context of Evaluating the Implementation of Acceptance Policy for New Students Through Independent Exams at USU. So the researchers chose to useEvaluation Model Stake's Countenance. In this study theevaluation model Stake countenance used includes three stages or three phases namely antecedents (initial conditions), transactions (implementation process), outcomes (results obtained). The researcher used Stake's (1967) countenance model (Taybnafis, 2008: 21) because this model according to Taybnafis was that the analysis of the evaluation process presented by Stake had a considerable impact on the evaluation field and was conceptually very strong. (Stake, 1967). Data collection techniques use analysis of literature studies, secondary data documents, observations, and in-depth interviews that support the validity analysis. The results of this study illustrate: (1) the preliminary phase process (formulation of policy making), (2) the phase of the transaction (planning, implementation, organizing, and supervisory policy (3) the phase of the results of the implementation of independent examinations in accepting new students at the University of Sumatra North In accordance with the Stake model, this paper describes two main ways of processing descriptive evaluation data, the contingency between antecedents, transactions and

Revised Manuscript Received on September 22, 2019.

Suandi Silalahi, Post Graduated Departmen Of Educational Managemen Universitas Negeri Jakarta , : suandisilalahi22@gmail.com

Sugiarto, Lecturer at Universitas Negeri Jakarta , sugiarto@unj.ac.id, Nurhattati, Lecturer at Universitas Negeri Jakarta nurhattati@gmail.com,

Suryadi, Lecturer at Universitas Negeri Jakarta , suryadi@unj.ac.id

Eliana Sari, : Lecturer at Universitas Indonesia, eliasanasari@unj.ac.id results and finding conformity between the intensity and observations of each phase and assessment made by evaluators based on certain standard criteria. results that can be one of the references in the new student admission policy at PTN.

Index Terms: Evaluation, Policy Implementation, New Student Admission, outcome

\section{INTRODUCTION}

The Unitary State of the Republic of Indonesia has a goal as mandated in the Preamble of the 1945 Constitution of the Republic of Indonesia, namely "... protecting the entire Indonesian nation and the whole of Indonesia's bloodshed and advancing public welfare, intellectualizing the life of the nation, and participating in carrying out world order based on independence, eternal peace, and social justice ... ". To realize this goal Article 31 paragraph (3) of the 1945 Constitution of the Republic of Indonesia mandates that the Government undertake and organize a national education system that enhances the faith and piety of God Almighty and noble character in order to educate the nation regulated by law. invited. In addition, Article 31 paragraph (5) mandates that the Government promote Science and Technology by upholding religious values and national regulations for the advancement of civilization and the welfare of mankind.

One level of education in the national education system is higher education. Higher education according to Law No. 12 of 2012 concerning Higher Education is the level of education after secondary education which includes diplomas, undergraduate programs, master programs, doctoral programs, and professional programs, as well as specialist programs, organized by universities based on the culture of the Indonesian nation.

Higher education is organized by universities, which in Indonesia are divided into State Universities (PTN) and Private Universities (PTS). PTN is a college that is established and / or organized by the government and PTS is a college that is established and / or organized by the community. The role of higher education is very strategic in advancing the life of the nation and state in all fields. Strongly influential countries have a history of developing good tertiary education. Kerr (1963), said: each nation, as it has become influential, has been tended to develop the leading intellectual institutions of its world (Kerr, 1963).

Therefore, almost all countries pay enormous attention to advancing higher education. In Indonesia too, conceptually the role of higher education is 
very large in realizing the goals of the country. Higher education, both held by the government (PTN) and the community (PTS), is not excessive if it is said to be the front guard in educating the nation's life, by developing science and technology to advance public welfare and social justice for all Indonesian people.

In a growing world, besides increasing the intensity of cooperation between countries as well as growing competition. Globalization is both competition. To improve national competitiveness, universities also carry enormous responsibilities.

Higher education funding is very strategic in advancing the life of the nation and state in various fields. Countries that have strong influence in the world are countries that have a history of developing good tertiary education. Kerr in The Uses of the University said that each nation, as it has become influential, has been developed to develop the leading intellectual of its world.

So that it can be said that almost all countries pay enormous attention to advancing higher education in their respective countries. That the Unitary State of the Republic of Indonesia in terms of education, including in the case of higher education managed in higher education, has the objectives as mandated in the Preamble of the 1945 Constitution, namely "..... protecting the entire Indonesian nation and the entire bloodshed of Indonesia and to promote public welfare, educate the world of life of the nation, and participate in carrying out world order based on freedom, eternal peace. So to realize this goal article 31 paragraph (3) of the 1945 Constitution saved so that the Government sought and organized a national education system that improved the faith and piety of God Almighty and noble character in order to educate the life of the nation.

Furthermore, in article 31 paragraph (5) mandates that the government advance science by upholding religious values and national regulations for the advancement of civilization and prosperity progress. Law No. 12/2012 concerning Higher Education is the level of education after secondary education which includes diplomas, undergraduate programs, master programs, doctoral programs, specialist programs and professional programs held by universities based on the culture of the Indonesian nation.

In Indonesia the process of higher education is organized by universities, namely State Universities (PTN) and Private Universities (PTS) Higher education which the learning process is in State Universities managed by the government. One of the important things in advancing higher education is the process of accepting new students. When this research was conducted until now, there were three types of new student admissions methods conducted by the government along with PTN, namely SNMPTN which was also called the invitation pathway, SBMPTN which was also referred to as the written test, and an independent test conducted by each PTN (including the Mandiri Exam at the University of North Sumatra).

SNMPTN and SBMPTN are selection paths conducted nationally, while the examinations are independently carried out by each PTN. Indeed, since the reform era, the government introduced PTNs to accept new students in certain julah, meaning that PTNs were given the authority to set education fees that must be borne by students who were accepted through this route. Indeed, with the independent admission of new PTN students and the cost of their education independently which is borne by the students themselves, there was a response between them agreeing and disagreeing. Even a small number of people thought that the process of independent student admission was an education liberalization which could not be separated from skenerio global urging WTO countries to liberalize 12 service sectors, one of which is education.

If viewed from the aspect of human resource development, especially in the process of higher education in PTN, then it is appropriate to require community involvement. In this case the policy of accepting PTN new students independently is one of the efforts to increase the number of people or high school graduates and equivalent to get the opportunity to study at PTN. So, based on the aspects of opportunity and needs, and their benefits, the government issues National Minister of Education Regulation and Permenristekdikti which states that in admission of new undergraduate students in addition to SNMPTN and SBMPTN, new PTN students can be accepted through the exam independently, which is $30 \%$ at most study programs or faculty at PTN.

In evaluation research, the implementation of the evaluation of new students through independent examinations at USU researchers chose to use the Stake evaluation model ormodel countenance. The Stake evaluation model ormodel countenance explains that evaluating or evaluating has the following steps: a) explain the program or policy, b) report the information to interested parties, c) get and doanalysis judgment, d) report back the results of the analysis. In the Stake evaluation model there is also something called a responsive model. This responsive model aims to provide attention by evaluators and those involved in assessment. evaluation model of Stake (1976) is a model that analyzes the evaluation process that analyzes and places a simple basis with a concept that is strong enough in the evaluation. Stake in the use of evaluation models suggested on evaluation researchers to apply two types of operations, namely, descriptions(descriptions)and judgment(judgment).To carry out these two types of operations, the evaluation of the implementation of the program / policy can be traced and elaborated through three phases or three stages of program / policy evaluation.

As for the three stages or three phases, themodel policy evaluation model Countenence Stake'sis as follows: (1) antecedent;(2) transaction; and (3) outcomes. This is because the focus of the research and formulation of the research problems is included in the three stages above, namely: 
Early Stage (Phase antecedents)

In this stage, the focus of attention is: (1)) aspects legal (juridical, related to legislation or regulations that become the justification of the technical and mechanism for implementing policies, both in terms of content and the legal hierarchy; and (2) conceptual understanding of USM policies for implementing parties and users of USU policies, students, and student parents, as well as the similarity of perceptions of each party to the USM policy concept.

Implementation Phase (Transaction Phase)

In this stage of concern aspects of the implementation which includes the preparation, coordination / organization of resources, implementation, monitoring (controlling), review (monitoring) /supervisidan job evaluation. In addition, at this stage, the supporting and inhibiting factors were also examined in the implementation of USM policies.

Stage of Policy Results (Outcome Phase)

In this stage, the concern is the outcome aspect of policy implementation, which includes: (1) short-term results (shorth term result) and long-term results (long term result); (2) the desired outcome (intended outcome) and unwanted results (unintended outcome); and (3) added value felt by executors and users of USM policies (USU, students, student parents). The short-term results here are the results caused by the implementation of USM policies in less than 1 year, and the long-term results are the results caused by the implementation of USM policies over one year. In other words, the evaluation of the outcome is intended to determine the extent to which the success rate of the implementation of the policy that has taken place is in accordance with the goals and objectives of the policies previously set.

\section{LITERATURE REVIEW}

\section{A. Evaluation}

Evaluation(Evaluating)is a systematic effort to collect and process the information that led to the conclusion about the value, benefits, and performance of the educational institution or unit performance of educational institutions or work units are evaluated, and then use the evaluation results in the decision-making process and planning (Rohman \& Wiyono, 113) There is an underlying sequence or process before evaluating, namely:

First, develop the concept and conduct initial research. The concept needs to be carefully planned before the execution of the message is held and a trial needs to be conducted to check the compatibility between the drafts made with the execution of the message. Second, with the trial conducted, the evaluator tried to find a response, this response was important to be able to measure the effectiveness of the message delivered.

In conducting an evaluation process there are several things that must be discussed, namely: what is the material of the evaluation, why it is necessary to conduct an evaluation, where the evaluation is carried out, and the parties who conduct the evaluation. So, in general the evaluation process is divided into the beginning (pretest) and at the end (posttest). Pretest is an evaluation that is held to see the achievement of goals and serve as input for the next situation analysis.

In the context of this evaluation research, it is to see and assess whether USU's UMBPT PPL up to the level of supervision has conducted an evaluation of the organizers of PTN's new student admission policy at USU. Whether the implementation of the independent exam at USU, which is institutionalized in the USU PPL / Outlet committee, is in line with the policies set out in the National Education Ministerial Regulation, Minister of Research and Technology, PPL Guidelines, and USU Chancellor's Decree, starting from preparation and planning, implementation, supervision and monitoring.

According to the Big Indonesian Language Dictionary (KBBI) (2016), the word "evaluation" can be interpreted as "assessment". So, simply evaluation can be interpreted as an activity to assess or see the success or failure of a program carried out by individuals, organizations or government agencies. According to Dunn (2003), the term evaluation has a related meaning, each pointing to the application of several value scales to the results of policies and programs. In general, the term evaluation can be equated withappraisal, giving a number (rating) and assessment (assessment), words that express an effort to analyze policy outcomes in terms of unit values (Dunn, 2003).

In a more specific sense, evaluation is concerned with the production of information about the value or benefits of policy outcomes. When the results of a policy in reality have a value, this is because the results contribute to the goals or objectives. In this case, it can be said that policies or programs have reached a meaningful level of performance, which means that policy issues are made clear or overcome (Dunn, 2003). Parsons describes several definitions of evaluation, such as by Dye which offers a good broad definition when he notes that policy evaluation is "learning about the consequences of public policy", policy evaluation is an objective, systematic and empirical examination of the effects of public policies and programs on the target in terms of the objectives to be achieved (Parsons, 2008)

In evaluation research, Weiss, also quoted by Parsons, said that evaluation can be distinguished from other forms of analysis based on six things:

First, evaluation is intended for decision making, and for analyzing problems as defined by decision makers, not researchers.Second, evaluation is character evaluation. Research aims to evaluate program objectives.Third, evaluation is research carried out in settings policy, not in settings academic.Fourth, evaluation often involves conflicts between researchers and practitioners.Fifth, evaluation of costs is not published.Sixth, evaluation may involve researchers in issues of loyalty to funding agencies and increased social change (Parsons, 2008).

Blue Eyes Intelligence Engineering \& Sciences Publication 
Dye in Parsons, defining policy evaluation is an objective, systematic and empirical examination of the impact of public policies and programs on targets and objectives to be achieved (Dunn, 2003). This explanation or opinion is supported again by The Joint Committee's (1994) in Stufflebeam and Shinkfield which states that evaluations are the systematic assessment of the literature or merit and object Wibawa, et al., 1994). More in detail, Weiss in Parsons. In this study the evaluation meant evaluation of public policy, meaning that researchers conducted an objective, systematic and empirical examination, namely what things the government (Ministry of Research, Technology and Higher Education together with PTN) held the Independent Screening Exam. Furthermore, the stages of policy making, policy content, implementation of policies and the factors that inhibit them, as well as theoutcomesof the implementation of the Mandiri PTN Sieve Exam policy. Next, related to the purpose and benefits of evaluating Stufflebeam and Shinkfield stated:

"Evaluation is vital. The continuing health component of organizations will have a good understanding of which elements are strong and where changes are needed. Evaluation therefore is a positive pursuit " (Stufflebean \& Shinkfield, 2007).

The contemporary argument about meaning and the role of evaluation considers evaluation to be a systematic activity carried out to help audiences to be able to consider and increase the value of a program or activity. This definition includes four dimensions of evaluation (Mutrofin, 2010).

\section{B. Definition of Public Policy Public}

Policy is a series of actions that are definitively linked to the goal. In the political context scholars have an interest in institutional processes, namely a series of operations that are associated withlegislators, executives, bureaucracies and other related institutions (Jones, 2014). In defining the above process there are three approaches that can differ in the analysis points and the nature (nature) of their generalizations, but are not conflicting. This means that each approach is no more valid than the other approaches, in fact, all three of them provide full understanding (Jones, 2014).

So each approach to the process, namely institutional, group, and policy, together offers an effort to describe and analyze facts. As for the word policy, which is made into one phrase into a policy process, it is sometimes used and intended for meaning with specific objectives, programs, decisions, proposals (Jones, 2014). However, in everyday conversations between decision makers and colleagues, this shift in meaning is not essential. Generally in relations or certain technical or administrative links this word has a specific reference that is understood and understood by a group of policy makers or program makers. Thus, to be understood and understood by the public, not only understood and not only understood by certain groups, what was the actual policy, Eulau and Prewitt proposed a definition of policy. "The policy is the decision remains characterized by consistency and repeatability(repetitiveness)behavior of those who make and of those who adhere to the decision."

As a policy evaluation, according to Winarno, in Public Policy, Theory, Process, and Case Studies (2011: 228-229) said that policy evaluation is intended to see the causes of failure of a policy or to find out whether the public policies that have been implemented have an impact which are desired. Furthermore, in determining the evaluation of the implementation of the policy evaluation of PTN new students through independent examinations (in the Local Organizing Committee of UMBPT, University of North Sumatra) based on the scope of policy (Tilaar and Nugroho, 2009: 231) within the framework of management functions states that policy implementation is in nature framework for organizing - leading controling. Then, in evaluating this study the policy evaluation model is a model based on policy stages that include, such as: Antecedent Phase, Tansaction Phase, and Outcome Phase (Stake, 2000; 350). So, this evaluation research is carried out in the hope that it can provide positive input for improvement in terms of implementing the PTN's new student admission policy, specifically for the implementation of UMBPT in USU's PPL.

Finally, this evaluation research aims to explain the effectiveness of the implementation of new student admissions through examinations independently at USU PPL, especially the extent to which it produces results, namely opportunities, benefits as real needs for high school graduates and equals and the real needs of USU as UMBPT. As for operationally, this evaluation research aims to obtain an explanation of the ongoing implementation of UMBPT in USU PPL.

\section{METHODOLOGY/MATERIALS}

In general, research evaluating the policy of admitting PTN students through examinations independently at USU's PPL was conducted to obtain and to find accurate and reliable information and explanations regarding its implementation. The evaluation model chosen in conducting this research is the Stake model which includes the Antecedents phase, transaction phase, outcome phase. The method used in this evaluation research is a qualitative method through observation (observation) in-depth open interviews (evaluation research). So this research is conducted to obtain valid and reliable information starting from the initial condition (antecedents phase) and certainly about the outcome of the policy (outcome phase).

This study lasts for 7 (seven) months, starting in August 2016 until August 2017, with details as follows: 
Table 1 Research Time

\begin{tabular}{c|c|l}
\hline NO. & TIME & OF ACTIVITIES \\
\hline 1. & $\begin{array}{l}\text { July to } \\
\text { August } \\
2016\end{array}$ & $\begin{array}{l}\text { Management of research } \\
\text { permits and preparation } \\
\text { of in-depth interview } \\
\text { guidelines in accordance } \\
\text { with selected research } \\
\text { models Improvement of } \\
\text { theStake's Countenance } \\
\text { Model instrument }\end{array}$ \\
\hline 2. & $\begin{array}{l}\text { August } \\
2016 \text { to } \\
\text { February } \\
2018\end{array}$ & $\begin{array}{l}\text { Observation, in-depth } \\
\text { interviews and data } \\
\text { collection }\end{array}$ \\
\hline
\end{tabular}

Policy evaluation is one of the objects of evaluation research. This study was conducted to obtain valid information and can be trusted on the initial conditions (antecedents), policy implementation, and variations in the results (outcomes) Exam Independently implementation at the University of North Sumatra. In evaluating the aspects of the Exam independently by USU, it is carried out through a formal evaluation approach. Formal evaluation uses laws, program / policy documents, interviews with office holders in this case as policy implementers by identifying, defining, and specifying policy objectives and targets (Luankali, 2007). In formal evaluation the type of evaluative criteria that is most often used is effectiveness. Evaluating the implementation of the Examination Policy independently at the University of North Sumatra as an object of research to: (1) assess how much a policy can achieve its objectives; (2) provide guidance to policy implementers regarding how smoothly the trip or the policy process is implemented; and (3) providing important indicators for policy makers in the future; and furthermore, (4) evaluating the outcome (outcome) of the policy is aimed at seeing the extent to which the results of the policy implementation result. In this evaluation, measures and interpretations of the success of the policies are carried out which include: evaluation; implementation of new student admission policies through the Independent Examination at USU.

This study combines descriptive and prescriptive methods. Descriptive methods are used to critically describe USM policy implementation at USU. While prescriptive methods are used to analyze policy choices about USM at USU. Descriptive and prescriptive methods are juxtaposed with policy research methods that can be divided into two, namely policy analysis (analysis of policy) and analysis to formulate policies (analysis for policy). Analysis of policy is more descriptive and analysis for policy is more prescriptive. (Luankali, 2007). Based on the type of data used, this study will use a qualitative approach with the library study data collection technique as a secondary data source and in- depth interviews (primary interviews) as primary data sources.

\section{RESULTS AND FINDINGS}

The process, formulation, and making of PTN new student admissions policies through independent examinations, specifically UMBPT in USU's PPL is based on needs, interests, and benefits as well as to provide wider opportunities to the community (high school graduates and equivalent). As for the benefits and more opportunities to compete through examinations independently so that if they are accepted through an independent examination they can study at PTN. The policy of PTN new student admissions through independent examinations regarding the relationship and its relationship with a set of rules and legislation between policy makers and policy implementers, based on the results of interviews with evaluation researchers explained that conceptually they could understand and understand it. So that in the implementation of the implementation even the policy of accepting new PTN students through independent examinations at PPL Universitas Sumatera Utara can proceed and take place in accordance with what is expected and desired. Likewise before the implementation of the policy, the stages of policy making are in accordance with procedural processes.

The point, according to procedural, is that the stage of policy making begins with identifying issues, forming a formulation team, formulating a policy from (draft zero), discussing it in a discussion forum together with a public forum (draft one) then continuing the discussion and verifying the draft one (final formula ) and endorsement. And all the policies of PTN new student admissions through independent examinations at USU PPL have a clear and directed orientation, also have clear goals and objectives, essentially all of which include the contents of management functions, in the form of: preparation and planning, coordination, procedures implementation, supervision, monitoring and implementation costs.

In terms of the implementation of PTN's new student admission policy on the USU PPL related to planning, provision of facilities and infrastructure, coordination, the implementation of monitoring and evaluation is considered to have met the criteria for accuracy, adequacy of responsiveness and in accordance with the UMBPT Guidance, Rector's Decree, University of North Sumatra , which is made based on Permenristekdikti No. 15 and No. $45 / 2015$. In carrying out and holding an independent test or UMBPT at the University of North Sumatra, starting from preparation, registration of participants, making questions, questioning, distributing questions, supervising written test participants until the written examination is completed or collecting answer sheets all done according to and based on the Guidebook UMBPT and recorded in the minutes. Furthermore, related to the results of the implementation of an independent PTN new student admission policy at the University of North Sumatra, based on interviews with students, parents, and PPL, they said that the test independently provided effective results as a result of being able to study at USU. And the effective benefit for

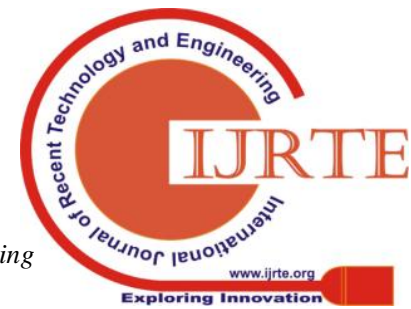


USU is that USU can provide a wider service process for higher education to the community.

\section{DISCUSSION}

After evaluating and based on the evaluation results of the Implementation of New Student Admission Policies Through UMBPT / Mandiri Examination at the University of North Sumatra, researchers obtained research findings in three stages, namely thestages outcome following:

The implementation of the new student admission policy through UMBPT / Mandiri Examination at USU in the order of the outcome components includes the results of implementation and the existence ofadded valuefor the users of the policy.

\section{A. Results Of The Implementation Of UMBPT Pathways / Independent Examination Of New Student Admission Policy At USU}

As for the first exposure in the steps of the outcome component stages are as follows:

First, the allocation of capacity of USU students through four paths, namely the PMP pathway, the SNMPTN pathway, the SBMPTN pathway, and the UMBPT / Mandiri Exam pathway at USU from 2010 to 2016 in seven faculties.Second, the percentage of students accepted at USU from seven faculties was noted that students through the SNMPTN and SBMPTN pathways were of a greater percentage compared to students who were accepted through the UMBPT / Mandiri Examination pathway at USU.Third, new students accepted through the UMBPT / Mandiri Examination at USU from 2010 to 2016 are volatile, namely: 2010 received 19\%, 2011 received $36 \%, 2012$ received $42 \%$, 2013 received 0\%, 2014 accepted 33\%, 2015 received 33\%, and 2016 received $25 \%$.

The explanation and explanation above can be summarized in the bar graph below as a comparison of the number of students accepted at USU through four channels in seven faculties.

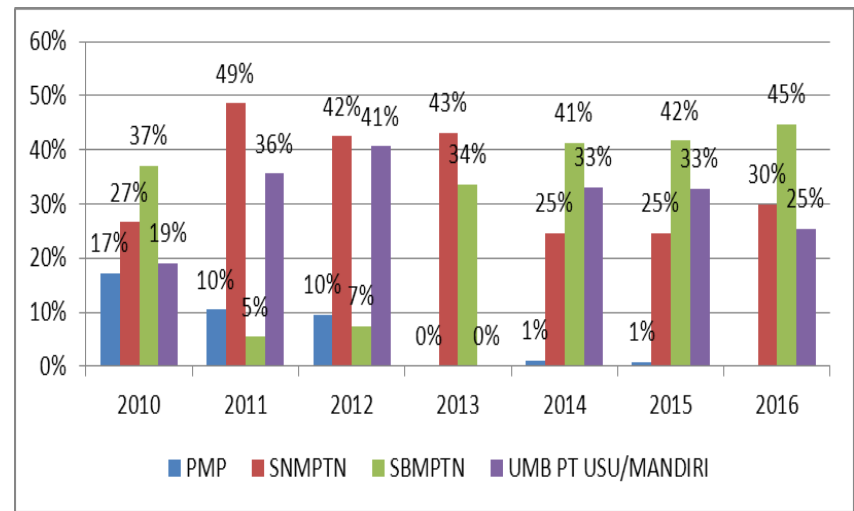

Source: Processed from the Head of Academic Affairs Bureau of the University of North Sumatra Chancellor

Fig 1. Comparison Chart of Number of USU Students

Received Through Four Paths: PMP, SNMPTN, SBMPTN, and UMBPT USU / MANDIRI TA. 2010-2016

\section{B. Implementation Or Implementation Costs.}

In Minister of Research, Technology and Higher Education Regulation Number 45 of 2015 concerning New
Student Admission at PTN, it is not explicitly stated about the cost of implementing or administering the exam independently. It is an important factor and there must be a cost for organizing the USU UMBPT / Independent Examination.

This important matter by Tilaar and Nugroho suggests that an important factor in implementing policies is the availability of budget ( Tilaar \& Nugroho, 2009). Based on the results of the interview research and according to the Guidelines for the Implementation of UMBPT / Independent Examination at USU, it was stated that the cost of the administration was borne by participants participating in the UMBPT / Mandiri Examination at USU. That the costs of organizing UMBPT / Mandiri Exams at USU are a burden and the responsibility of the participants already has conformity with the naming of the exam independently in the Minister of Research, Technology and Higher Education Regulation concerning the Admission of New Student PTN.

So, Implementation of the New Student Admission Policy Through UMBPT / Mandiri Examination at USU from the aspect of the cost component of implementation has met the criteria of adequacy.

\section{Supporting And Inhibiting Factors Of Implementation}

In a broader sense, policy implementation is an administrative tool of various factors, for example, actors, organizations, procedures and techniques that jointly work to carry out policies to achieve desired impacts and objectives. The success of policy implementation is influenced by the preconditions needed, namely, the existence of supporting factors and the main obstacles that must be faced, according to Edward in Budi Winarno, Public Policy. (Winarno, 2012).

The planning process itself cannot be seen as a separate process from implementation. Of course at the implementation stage various forces will influence both the factors that support or encourage and also the factors that hinder the implementation of the policy. In the context of the implementation of the policy of admitting new students through UMBPT / Independent Examination at USU, they also experience supporting and inhibiting conditions as factors that exist in their implementation. However, related inhibiting factors are smaller than supporting factors so that the problems that become the inhibiting factors for each of the resources in the PPL UMBPT / Mandiri Exam at USU can be anticipated and overcome by means of a coordinated collaboration organization. By coordinating with fellow resources in the PPL UMBPT / Mandiri Exam at USU, it can be carried out as desired and fulfills the criteria 


\section{CONCLUSION}

1. That the independent policy making exam for new student admissions at USU has been based on needs, interests, and also benefits. The needs, interests and benefits of the community in question are in the case of students who graduate from high school and equivalent who have not been accepted through SNMPTN, SBMPTN. Then for USU as the organizer of this policy the interests of higher education, especially at USU while getting added value. The intended added value for USU is:

First, USU as a PTN through the existence of exam policies independently got the opportunity to get additional funding from the community to manage the higher education process at USU.

Second, with the abandonment of the new student admission policy independently at USU, it can provide motivation and enthusiasm for the learning and teaching process for students and lecturers.

Indeed, before the implementation of an independent PTN new student admission policy, especially at USU, there were differences of opinion among the community and education practitioners. However, based on this evaluation research, related to the act of regulation to be able to take into account the policy of acceptance of stone students independently at USU VAT that the stages of making this policy have been carried out in accordance with the new procedure. The purpose in accordance with the correct procedure is to start and initiate it by identifying issues, forming a formulation team. Thus, the Formulation team started from zero draft. With the zero draft this was discussed with a public forum (the result was draft-1). Furthermore, draft 1 is discussed again and verified to find and produce the final draft endorses.

In implementing the policy, including the implementation of an independent PTN student admission policy and USU PPL must have a clear orientation and essence, the purpose is not to be free from management functions.

So, in the implementation of the PTN new student admission policy independently in USU PPL management functions, such as preparation and planning, coordination, implementation, supervision, monitoring, and evaluation, the implementation was implemented properly and correctly.

Thus, it can be concluded that starting from the policy making process, the implementation of the policy of accepting new students independently at USU PPL is processed and carried out correctly by implementing management functions. The management functions are arranged in one UMBPT guidebook.

2. That the implementation of PTN's new student admission policy in USU PPL is based on the criteria of accuracy, adequacy, and responsiveness that have been carried out through the process of preparation and planning, the availability of facilities and infrastructure, coordination of human resources, supervision and evaluation.

This is done according to USU's UMBPT / PPL Guidebook and USU Chancellor's Decree. Based on the results of open and in-depth interviews with several parties (USU PPL Chair who is also USU's Vice Chancellor-I, 11 Core PPL personnel, 5 Faculty Deans, as policy implementers at USU PPL, then starting from socialization or registration information, how to register, majors selection), making UMBPT questions, doubling questions, distributing questions up to the implementation of UMBPT written exams in USU PPL is taking place in accordance with the UMBPT Guidebook, so that related to supporting and inhibiting factors, it is almost impossible for inhibiting factors because all HR do it in a planned, coordinated, organized according to the technical instructions in the USU Chancellor and Decree

3. Based on the results of the interview and according to the Guidelines for Higher Education Entrance Entrance Examinations and USU Chancellor's Decree No. 1031 / UN.5.1.R / SK / SPB / 2016 in the CONSTITUTION DECIDES, the third point is that the costs incurred are borne by the USU PNBP 2016 budget. Furthermore, regarding the costs that must be borne by UMBPT participants, according to Dr. Muhammad Fidel Ganis Siregar (Vice Chancellor II of USU) is in accordance with the exam group chosen by UMBPT participants, namely the Research Group, Social Sciences and Mixed groups.

When researchers conducted open interviews with students who were accepted through an independent examination at USU about whether the registration fee was more expensive than the SBMPT registration fee? In general, more said, yes, more expensive. However, also in general they and also their parents who are providers of UMBPT registration fees, said it was not a problem. Why? Their general answer said that they had prepared more importantly they could study at USU.

4. Based on the data processing of students who were accepted through independent examinations (UMBPT), PMP, SNMPTN, SBMPTN whose sources were from the USU Academic Bureau, there were inconsistencies in the number and percentage of students received through UMBPT starting from 2012, 2013, 2014, 2015, 2016, 2017 and 2018.

That is, based on the processed data as described above the researchers concluded that the number of students in the percentage found inconsistency.

\section{ACKNOWLEDGEMENTS}

This research work is supported by Universitas Negeri Jakarta.

\section{REFERENCES}

[1] Balai Pusat Bahasa Departemen Pendidikan Nasional. (2016). Kamus Besar Bahasa Indonesia Edisi Ke-5.

[2] Dunn, William N. (2003). Pengantar Analisis Kebijakan Publik, Edisi Kedua, Yogyakarta: Gadjah Mada University Press. 
[3] Jones, Charles O. (1991). An Introduction to the Study of Public Policy, Diterjemahkan oleh Riky Istamto. Jakarta : CV.Rajawali.

[4] Jones, Charles O. (1984). An Introduction to the Study of Public Policy, Third Edition, Monterey: Cole Publishing.

[5] Kerr, Clark. (1963). The Uses of University, California: Torch Book The Academy Library.

Luankali, Bernadus. (2007). Analisis Kebijakan Publik Dalam Proses Pengambilan Keputusan, Penerbit Amelia Press, Jakarta.

[6] Mutrofin. (2010). Evaluasi Program, Teks Pilihan untuk Pemula Penerbit Laks Bang Pressindo, Yogyakarta.

[7] Parson, Wayne. (2008). Public Policy, Pengantar Teori dan Praktik Analisis Kebijakan, Penerbit Kencana Prenada Media Group, Jakarta.

[8] Stufflebeam, Daniel L. dan Anthony. (2007). Evaluation Theory, Models and Aplication, San Fransisco: Jossey Bass.

Stake, Robert E. (2000). Program Evaluation, Particulary Responsive Evaluation, diedit oleh Daniel L. Stufflebeam, George F. Madaus and Thomas Kellaghan, Evaluation Models, Vewpoints on Educational and Human Services Evaluation, Second Edition, New York, Boston, Dordrect, London, Moscow: Kluwer Akacemic Publisher.

[9] Winarno, Budi. (2012). Kebijakan Publik, Teori, Proses, dan Studi Kasus, Penerbit CAPS, Yogyakarta.

Tilaar, H.A.R dan Riant Nugroho. (2009). Kebijakan Pendidikan, Jakarta: Pustaka Pelajar.

[10] Tilaar, H.A.R dan Riant Nugroho. (1999). Beberapa Agenda Reformasi Pendidikan Nasional Dalam Perspektif Abad Ke-21, Jakarta :Terra Indonesia.

[11] Usman, Husaini (2011). Manajemen: Teori, Praktik dan Riset Pendidikan, Jakarta: Bumi Aksara

Undang-Undang Dasar Negara Republik Indonesia Tahun 1945 Pasal 31 ayat 5

[12] Undang-Undang No. 12 Tahun 2012 Tentang Pendidikan Tinggi

\section{AUTHORS PROFILE}

Suandi Silalahi from Post Graduated Departmen Of Educational Managemen Universitas Negeri Jakarta. My area of interest is public policy reseach and development.

Sugiarto, Lecturer at Universitas Negeri Jakarta , sugiarto@unj.ac.id. My area of interest is education and public policy.

Nurhattati, Lecturer at Universitas Negeri Jakarta. My area of interest is public policy reseach and development.

Suryadi, Lecturer at Universitas Negeri Jakarta. My area of interest is public policy reseach and development.

Eliana Sari, Lecturer at Universitas Indonesia, My area of interest is public policy reseach and development. 